\title{
Powerful Lipolytic Activity of Fungi Isolated from Coconut and Avocado Flesh on Different $\mathrm{pH}$ and Temperature
}

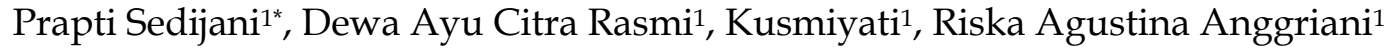 \\ ${ }^{1}$ Departement of Teacher Training and Education, University of Mataram, West Nusa Tenggara, Indonesia
}

DOI: $10.29303 / j p p i p a . v 7 i S p e c i a l I s s u e .1261$

\section{Article Info}

Received: November $5^{\text {th }}, 2021$

Revised: December 21st, 2021

Accepted: December 25th, 2021

\begin{abstract}
Lipase is widely applied in various fields of industries elevating its economic value. The demand for lipase keeps increasing open up working opportunities. Isolates showing lipolytic activity obtained previously are tested for their activity on different $\mathrm{pH}$ mediums: 7, 8, 9, and 10; and at different temperatures. The fungi are grown on SDA medium supplemented with Olive Oil, emulsifier, Tween 80, and Rhodamine B. The experiment was made in 3 replicates and is incubated at room temperature of $30^{\circ} \mathrm{C}$. Lipase activity was calculated based on the clear zone around colonies observed on day 2 and day 3 after inoculation. The result shows that those isolates are highly active on various $\mathrm{pH}$ at $\mathrm{RT}$, and the activity slightly reduces at $30^{\circ} \mathrm{C}$. This result suggests that a wide range of their applications are at room temperature when $\mathrm{pH}$ is a limiting factor for the applications.
\end{abstract}

Keywords: Lipase Activity; Coconut; Avocado; pH; Temperature

Citation: $\quad$ Sedijani, P., Rasmi, D.A.C., Kusmiyati, K., \& Anggriani, R.A. (2021). Powerful Lipolytic Activity of Fungi Isolated from Coconut and Avocado Flesh on Different $\mathrm{pH}$ and Temperature. Jurnal Penelitian Pendidikan IPA, 7(Speciallssue), 365-369. https://doi.org/10.29303/jppipa.v7iSpecialIssue.1261

\section{Introduction}

Biocatalysts (enzymes) are replacing chemical catalysts in various commercial industries as increase human awareness of the environment (Kumari et al, 2019). Enzymatic reactions have several benefits in comparison to a chemical reactions. This reaction does not need high temperature, high pressure, or high energy. The reaction can be very specific, unnecessary products can be avoided, therefore no further processes are needed for the product. The enzyme can be immobilized spanning the use several times. The enzyme also can be used to remove waste to save the environment while itself is degradable (Pratush, et. al., 2013) as well as no harmful residue is produced (Hasan et al, 2010).

Lipases belong to the hydrolase group EC 3.1.1.3. plays a role in breaking down triglyceride fats into glycerol and fatty acids. Various bioconversion capabilities at extreme conditions such as high temperatures and $\mathrm{pH}$, in limited water and in non- polar solvents (Patel, et al, 1996) lipase is a very applicable enzyme in various commercials industrial fields, including food, drink, medicine, health, petroleum, agriculture and many others (Andualema and Gessesse, 2012).

Lipase can also be used for environmental bioremediation in oil spill areas and household, hotel, restaurant waste, to remediate used cooking oil (OkinoDelgado, et al., 2017). The latter is certainly very beneficial for traders who use cooking oil a lot, besides being cost-effective, it is also healthy for their customers. Moreover, lipase is used as a biosurfactant that can be added to various household cleaning gents (Hisham, et al., 2019). Enzyme-based detergent has become a positive trend that is environmentally friendly (Olsen and Fahlot, 1988).

For industrial purposes, lipases are generally produced from microbes for several reasons: the cheap and abundance of a substrate, the stability, the easiness to scale up production, shortness of time production, and the independence of season; they all make lipase 
production costs low (Guerrand, 2017; Pratush, et al., 2013; Wiseman, 1995).

Enzyme demand in Indonesia is enormous, especially for food processing, beverages, leather tanning, paper factories, and other industries. So far, $99 \%$ of demand is fulfilled by imported enzymes. In the year 2015 only imported enzyme was about 2.5 tons and expensed more than Rp 187 M (BPPT, 2015), disregarding the presence of the production within. Even though the imported enzyme is very expensive, however, it is still a better choice as it has higher activity than the domestic one. The expense for the enzyme to produce Bio-ethanol, for example, it reaches $30 \%$ of the total production cost (Bušić, et al., 2018).

Lipase production can be increased in several ways, including the selection of the right substrate, suitable environmental conditions $(\mathrm{pH}$, temperature), the type and concentration of nitrogen, and the addition of sugar with a certain concentration. The addition of $\mathrm{Fe} 2+, \mathrm{Mg} 2+$, Triton X100, Tween esters increases lipase production (Kumar, et al 2012). Each microbe, however, has its own needs and characteristics that should be understood to predict how/what situations enzymes can be produced using certain microbe and may describe the flexibility of its application fields. Temperature and $\mathrm{pH}$ are very important factors for growth, enzyme production, and enzyme activity. Enzymes purified from microbes often lose activity under alkaline conditions, the presence of surfactants, and high temperatures (Kumari, et al., 2019).

The increasing of lipase application, the characteristic of lipase that meets the need for the satisfactory operating system is a limiting factor, therefore the interest in finding new lipases that suit the application is still increasing (Gupta, et al., 2004).

Two pure fungal isolates recently isolated from coconut and avocado flesh show the lipolytic activity on screening medium. This report discusses their activity in a range of $\mathrm{pH}$ and temperature of the fungi.

\section{Method}

Isolates used were fungi recently isolated from coconut flesh and avocado flesh which showed lipolytic activity. The isolates were rejuvenated on a PDA medium before use.

The medium used for the experiment was SDA medium with the following addition: $1 \%$ olive oil as a carbon source and stimulant, $1 \%$ emulsifier and Tween
$800.05 \%$ so that the oil is evenly mixed and Rhodamine $\mathrm{B}$ as an indicator, $0.2 \%$ agar as solidifier and $\mathrm{pH}$ adjusted to $7,8,9$ and 10 . The medium was autoclaved for 15 minutes at $121^{\circ} \mathrm{C}$ and 1 ATM pressure. After the medium reached about $60^{\circ} \mathrm{C}$, the medium was poured into sterile petri dishes, about $25 \mathrm{~mL}$ medium per petri dish.

Fungal inoculation was performed using a sterile toothpick to transfer as little mycelium as possible and inoculated right in the middle of the medium. Experiments were made in triplicates and incubated at room temperature. The same experimental set was incubated at $30^{\circ} \mathrm{C}$. Observations were made on the 2 nd and 3rd days after inoculation. The clear zone formed around the colony indicated the presence of lipolytic activity.

Calculation of activity in a petri dish was carried out by measuring the diameter of the clear zone minus the colony diameter then divided by the colony diameter (Kouker and Jeager, 1997). Data obtained was analyzed using Two Way ANOVA Test (SPSS).

\section{Result and Discussion}

The appearance of the clear zone on a petri dish is presented in Figure 1 and the amount of activity is presented in Figure 2. Figure 1 shows the clear zone of the isolate at different $\mathrm{pH}$ and different temperatures. The control medium shows a darker color (opaque) which occurs due to a mixture of oil and the components of the medium. The inoculated medium showed a bright zone as a result of which the oil had been degraded by the isolate, which also meant that the isolate was active in producing lipase.

The observation picture on day 2 is brighter than day 3 and confirmed by numerical data (not shown) and the activity shown in Figure. This observation seems to be false data, that can be explained as follows: the colony diameter increased and covered part of the clear zone where the oil had been previously degraded, while the medium area on petri dish is fixed, so there is no more room to show further activity resulting false observation. The observations on day 3, however, provide information that for further research, data recording should be carried out on day 2. Observations on the first day of data are not recorded because the growth was still very small and the clear zone has not been seen. 


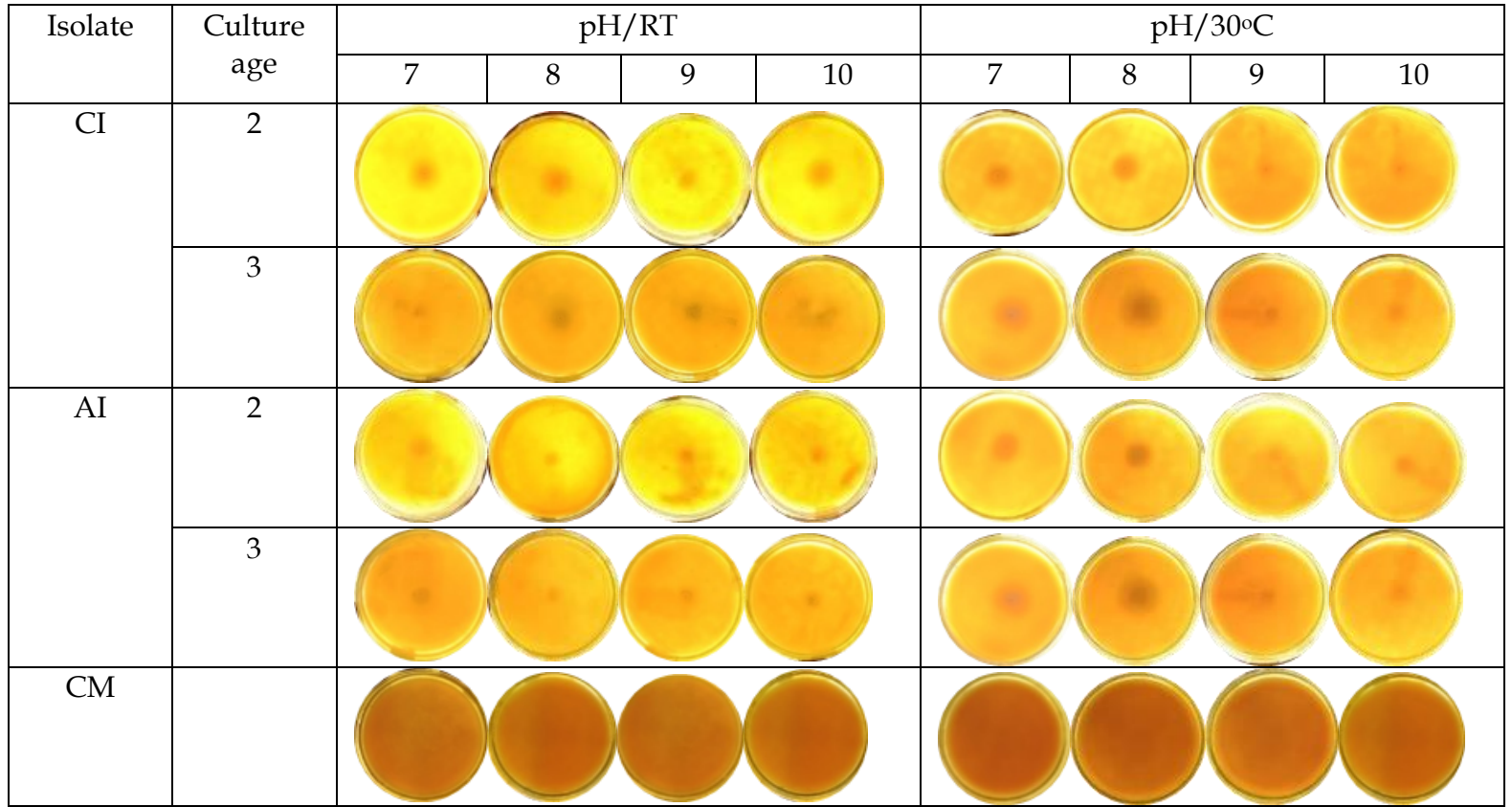

Figure 1. The clear zone formed due to lipolytic activity by $\mathrm{CI}$ and $\mathrm{AI}$ isolates (shown 1 of three replicates).

Note: $\mathrm{CI}=$ Coconut Isolate, $\mathrm{AI}=$ Avocado Isolate, $\mathrm{CM}=$ Control Medium

The lipolytic activity of the isolates is presented in Figure 2. The lipolytic activity at room temperature ranged from 284 to $400 \%$, while at $30^{\circ} \mathrm{C}$ it ranged from 151 to $245 \%$ multiples of the colony diameter. This difference is statistically significant $p<0.00$. Meanwhile, the differences in the lipolytic activity of both isolates in the medium with different $\mathrm{pH}$ were also significantly different statistically, $\mathrm{p}<0.009$. However, further tests using LSD show that not all treatments are different one from another activities in the medium with a $\mathrm{pH}$ range of $7-10$, this indicates that isolates are more flexible to be applied in the normal to high $\mathrm{pH}$ range. It can be seen on the petri dish that on day 2, the entire diameter of the petri has become a clear zone.

\subsection{0}

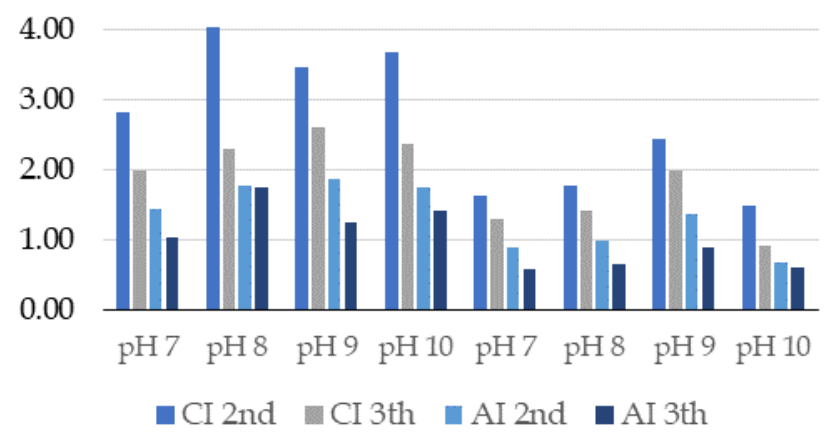

Figure 2. Lipolytic activity of $\mathrm{CI}$ and $\mathrm{AI}$ at room temperature (left) and $30^{\circ} \mathrm{C}$ (right) observed on the 2 nd and 3rd days. $\mathrm{CI}=$ isolate from Coconut; $\mathrm{AI}=$ Isolate from Avocado. The quantities indicated are multiples of $100 \%$ of the colony diameter.
If it is assumed that the olive oil has run out within 2 days, it can be roughly estimated that for 1\% olive oil in the medium, the content of the petri is about $25 \mathrm{ml}$, then the available oil is 250 micro liters/petri, which after calculating the fungal activity of 1 colony within each petri is $334 \mathrm{nM} / \mathrm{min}$. Again this is a rough calculation adopted by the calculation method by (Kouker and Jeger, 1987). The right observation time to see the right time to get a complete clear zone in petri dishes needs to be done to get more accurate data, as well as the amount of medium that is poured into each petri dish. This simple method can be used for isolation and at the same time observing its activity, for data verification, it is necessary to carry out further testing by titration or spectrophotometry or more advanced methods such as GCMS. This data, however, show the very active isolat on such a high $\mathrm{pH}$.

Statistically, there was nearly no significant difference between $\mathrm{CI}$ and AI isolates, $\mathrm{p}=0.0484$. This indicates that both isolates have the same potential to be used as source organisms to produce lipase which can be carried out at normal to high $\mathrm{pH}$ conditions and incubated at room temperature for the best, but at $30^{\circ} \mathrm{C}$ the isolate still shows any activity. Further characterization of the lipases of the two isolates needs to be done such as stability and other characteristics.

For industrial applications (Essamri, et al., 1998), lipase from Candida and Aspergillus sp (Savitha and Ratledge, 1991) and Geotrichum sp. (Ginalska, et al., 2004) are particularly important. The isolate has not been identified yet, however, the activity may have possible applications for alkaline conditions for 
example on detergent and its derivatives. It may be used such as soaking before washing or adding to powdered soap (Treves, et al., 1984), and in automatic dishwasher machines, lipase removes fatty residues and cleans clogged drains (Vulfson, 1994). Enzymebased detergents are becoming a trend lately that deserves to be followed. In Europe, for an instant, detergent industries are the largest consumer of enzymes production (Hasan, et al, 2010) along with the increasing concern of the society toward the green environment. Some of the advantages of using an enzyme-based detergent include increasing the level of cleanliness of laundry, shortening washing time, lowering the washing temperature, reducing the use of chemicals, reducing the use of water all of which save energy, and is environmentally friendly (Olsen and Falhot, 1998). Enzymes purified from microbes often lose activity under alkaline conditions, the presence of surfactants, and high temperatures (Kumari, et al., 2019). Lipase isolates from coconut flesh and from avocados still have high activity at $\mathrm{pH} 10$, maybe even more than 10 (needs to be roved), nevertheless detergent working at low temperature is beneficial for energy and environment and being sought of. Therefore, both isolates are potentially a good source for lipase production. Other applications are of course adapted to the needs, seeing that the lipases of the two isolates are quite flexible with the physical environmental conditions. Lipase flexibility to the chemical environment needs to be investigate.

\section{Conclusion}

Lipase of fungi isolated from Coconut and Avokado Flesh are highly active on $\mathrm{pH}$ normal to high alkaline ( $\mathrm{pH} 10)$, best on room temperature, slightly decline on $30^{\circ} \mathrm{C}$.

\section{Acknowledgement}

Highly appreciation forwarded to PNBP research funding which allow this research be conducted, thank you very much to Riska Anggriani who help to collect the laboratory data, Laboratory of Biology and laboratory of Chemistry FKIP Mataram University which facilitate a lot for data collection.

\section{References}

Andualema, B., \& Gessesse, A., (2012). Microbial Lipases and Their Industrial Applications: Review. Biotechnology, 11: 100-118. https:// doi.org/10.3923/biotech.2012.100.118

BPPT. (2015). Ciptakan Pabrik Enzim Pertama di Indonesia, BPPT Transfer Teknologi Produksi Enzim ke PT Petrosida Gresik. Retriwved from: https://www.bppt.go.id/berita-...gresik [Indonesian]

Bušić, A., Marđetko, N., Kundas, S., Morzak, G., Belskaya, H., Ivančić Šantek, M., Komes, D., Novak, S., \& Šantek, B. (2018). Bioethanol Production from Renewable Raw Materials and Its Separation and Purification: A Review. Food technology and biotechnology, 56(3), 289-311. https://doi.org/10.17113/ftb.56.03.18.5546

De OliveiraNatalia, R.J.V., de Sousa, M.F., Pinto, W.P., Bezerra, N.L., da Silva, G.A., \& Cavalcanti de QA (2020). Seasonality affects the community of endophytic fungi in coconut (Cocos nucifera) crop leaves. Acta Bot. Bras. 34 (4). https:/ / doi.org/10.1590/0102-33062020abb0106

Fueg, B.N., Romano,' K.G., Pinlac, C.D., \& Lirio, G.A.C. (2021). Evaluation of the Antimicrobial Activity of Endophytic Fungus Isolated from Cocos nucifera (L.) Cotyledon against Medically-Important Pathogens. Journal of Biosciences and Medicines 9(01) Article ID: 106786,12

https://doi.org/10.4236/jbm.2021.91007

Gennari, F., Strebdansky, S., \& Pizzio, F (1998). The Use of Biocatalyst for Industrial Application. Genetic Eng, Biotechnol. 4: 14-23

Guerrand, D. (2017). Lipase Industrial Application: Focus on Food and Agro industri. Oilseed \& Fat Crop and Lipid. 24(2): D403. https://doi.org/10.1051/ocl/2017031

Hasan, F., Shah, A.A., Sundus, J. \& Hameed, A. (2010). Enzymes used in detergents: Lipases. African Journal of Biotechnology. 9(31), 4836-4844.

Hisham, N.H.B., Ibrahim, M.F., Ramli, N., \& Abd-Aziz, S. (2019). Production of Biosurfactant Produced from Used Cooking Oil by Bacillus sp. HIP3 for Heavy Metals Removal. Molecules (Basel, Switzerland), 24(14), 2617. https://doi.org/10.3390/molecules24142617

Kouker, G and Jeager, K-R (1987). Specific and Sensitive Plate Assay for Bacterial Lipases. Applied Science and Environmental Microbiology. 1(53): 211-213.

Kumar, A and Kanwar, SS (2012). Lipase Production in Solid-State Fermentation (SSF): Recent Developments and Biotechnological Applications. Dynamic Biochemistry, Process Biotechnology and Molecular Biology @2012 Global Science Books

Kumari, U,, Singh, R., Ray, Tue, Rana S., Saha P., Malhotra, K., \& Daniell, H. ( 2019). Validation of leaf enzymes in the detergent and textile industries: launching of a new platform technology. Plant Biotechnol J.17(6): 1167-1182. https://doi.org/10.1111/pbi.13122 
Okino-Delgado., Prado, D.Z., Facanali, R., Marques, M.M.O, Nascimento, A.S., Fernandes, C.J.D., Zambuzzi, W.F., \& Fleun, L.F. (2017). Bioremediation of cooking oil waste using lipases from wastes. PLoS One. 12(10): https://doi.org/10.1371/journal.pone.0186246.

Olsen, H.S., Falholt, P. The role of enzymes in modern detergency. J Surfact Deterg 1,555-567 (1998). https://doi.org/10.1007/s11743-998-0058-7

Patel, M.T., Kilara, A., \& Nagarajan, R. (1996). Lipasecatalyzed biochemical reactions in novelmedia: A review. Chemical Engineering Communications 153(1): 365-404

Pratush, A., Gupta, A., Vyas, G., \& Sharma, P. (2013). Bacterial Lipases: Production Strategies and Industrial Applications. Microbiology Application. 64-83

Treves, C., M.T. Vincenzini, F., Favilli, P., Vanni, V. \& Baccari, (1984). On the interaction between synthetic detergents and enzymatic proteins. Canadian J. Biochem. Cell Biol., 62: 55-59.

Vulfson, E.N. (1994). Industrial applications of lipases in Lipases, ed. by Wooley P. and Petersen S.B., Cambridge, Great Britain: Cambridge University Press; p. 271.

Wiseman, A. (1995) Introduction to Principles. In: Wiseman, A., Ed., Hand Book of Enzyme Biotechnology, 3rd Edition, Ellis Horwood Ltd. T.J. Press Ltd. Padstow, 3-8. 